\title{
Research proposal on the relationship between corporate social responsibility and strategic human resource management
}

\author{
Jesús Barrena-Martínez*, \\ Macarena López-Fernández and \\ Pedro M. Romero-Fernández
}

\author{
Department of Business Management, \\ University of Cadiz, \\ Glorieta Carlos Cano S/N, \\ Cádiz 11002, Spain \\ E-mail: jesus.barrena@uca.es \\ E-mail: macarena.lopez@uca.es \\ E-mail: pedrom.romero@uca.es \\ *Corresponding author
}

\begin{abstract}
The purpose of this study is to develop a conceptual framework in order to analyse the relationship between corporate social responsibility and strategic human resource (HR) management. Thus far, both disciplines have advanced in isolation. Therefore, this paper aims to examine if a combination of these research lines can provide competitive advantages for enterprises. Specifically, we will analyse how a socially responsible orientation in the HRs practices can contribute to the achievement of these advantages through performance variables, such as work environment and intellectual capital.
\end{abstract}

Keywords: CSR; corporate social responsibility; intellectual capital; SHRM; strategic human resource management; working environment.

Reference to this paper should be made as follows: Barrena-Martínez, J., López-Fernández, M. and Romero-Fernández, P.M. (2011) 'Research proposal on the relationship between corporate social responsibility and strategic human resource management', Int. J. Management and Enterprise Development, Vol. 10, Nos. 2/3, pp.173-187.

Biographical notes: Jesús Barrena-Martínez is a Research Fellow in the Department of Business Management at the University of Cadiz. Currently, he is working towards a $\mathrm{PhD}$. His teaching and research interests include human resource management and corporate social responsibility. He has presented papers at international and national conferences.

Macarena López-Fernández is an Assistant Professor in the Department of Business Management at the University of Cadiz, where she teaches Human Resource Management. She was a Visiting Fellow at Limerick, Manchester and Reading Universities where she worked towards completing her $\mathrm{PhD}$ in Social Capital and Diversity. Her work has been presented at top international and Spanish conferences.

Pedro M. Romero-Fernández is an Associate Professor in the Department of Business Management at the University of Cadiz. His teaching experience (more than 15 years) spans the broad range of strategy, human resources and 
management. He has published his work in the field of HRM in peer-reviewed top national and international journals, such as the Int. J. Human Resource Management, British Journal of Management and the Journal of Business Research.

\section{Introduction}

The uncertainty of the current environment underscores the importance of institutional factors and intangible resources in the process of adaptation and firm's survival (GómezMejía and Balkin, 2002; Kang and Snell, 2009). Guided by theoretical perspectives, such as the resource-based view of the firm (Arthur and Boyles, 2007; Wright et al., 2001), human capital theory (Lepak et al., 2006) or social capital approach (Adler and Kwon, 2002; Moran, 2005), academics have demonstrated how human resources (HRs) represent a key mechanism to unlock the organisation's value and therefore one of the main sources of competitive advantages (Lengnick-Hall et al., 2009). Considering the framework proposed by Miles and Snow (1978), the success of an organisation is not based only on its internal strengths. Hence, it is necessary to establish a strategic fit between the internal resources of firms and their environment. To facilitate this adjustment, this study proposes an emergent strategic variable in management literature like corporate social responsibility (CSR) (Carroll, 1999; Galbreath, 2010; Lockett et al., 2006). CSR is defined as "the commitment of business to contribute to sustainable economic development, working with employees, their families, the local community and society at large to improve their quality of life" (World Business Council for Sustainable Development, 2000). The empirical evidence shows that those companies undertaking CSR actions can address more efficiently the pressures and social demands from the environment and their stakeholders (Bhattacharya et al., 2008a; Freeman et al., 2010; Husted and Allen, 2007).

Apart from these external benefits, the incorporation of CSR into business strategy can provide internal benefits to firms. In this sense, organisations that carry out a set of socially responsible practices:

1 appropriate employment relations and working conditions

2 communication, employee involvement and social dialogue

3 education and training

4 occupational health and safety

5 diversity and equal opportunities.

Literature on management shows that this kind of practices can generate a positive working environment among their employees (Bowen and Ostroff, 2004; Commission of the European Communities, 2001; Global Reporting Initiative, 2006; Gould-Williams, 2007; Muncherji and Gupta, 2004).

These circumstances improve the communication, trust and cooperation within organisation-social capital (Carmeli et al., 2009; Evans, 2005), and facilitates the exchange of knowledge, skills and attitudes among workers - human capital (Leana and Van Buren, 1999). As a result of these enhancements, the intellectual capital of the 
organisation will increase, encouraging the achievement of competitive advantages (Burgman and Ross, 2007; Youndt and Snell, 2004). If we add the importance of HRs into the development of business and CSR strategies (Lockwood, 2004; Sharma et al., 2009), we will reach the main objective of this study: to analyse whether a socially responsible orientation in the HRs practices can help companies to accomplish their goals and economic performance through two ways:

1 From an external adjustment between society and stakeholders expectations and their satisfaction by firms (Barnett, 2007; Harrison and Freeman, 1999).

2 From an internal adjustment between business strategies and HRs strategies (Lengnick-Hall and Lengnick-Hall, 1988; Miles and Snow, 1984; Wright and McMahan, 1992). In this regard, we focus on the improvements that this adjustment could generate in variables, such as working environment and intellectual capital (Surrroca et al., 2010; Youndt and Snell, 2004).

Following the institutional approach (Campbell, 2007; DiMaggio and Powell, 1983; Scott, 1995) and stakeholder's theory (Clarkson, 1995; Donaldson and Preston, 1995; Freeman, 1984), this study examine how organisations can achieve synergies stemming from CSR and strategic human resource management (SHRM).

\section{Theoretical background and research propositions}

In recent decades, the concept of CSR has gradually acquired greater importance in academic and professional fields (Carroll and Shabana, 2010; Crane et al., 2008). Researchers from different disciplines show how companies that incorporate social responsibility in their actions can achieve higher profits than their competitors (Table 1).

These studies illustrate how companies that develop CSR actions

1 can increase their financial performance

2 improve the relationship with their stakeholders

3 enhance the commitment of their employees.

However, little has been researched about the benefits of CSR practices in the HR management field (Cuganesan, 2006). Until now, different researchers have emphasised the relation of HRs in the implementation and develop of CSR objectives and strategies (Garavan and McGuire, 2011; Sharma et al., 2009). In this manner, Rupp et al. (2006) highlight that organisations which carry out CSR practices can achieve more satisfaction and commitment from their employees. According to a study conducted by Sirota Survey Intelligence $^{1}$ (2007) in more than 70 companies during $2007,70 \%$ of workers are more satisfied and committed to those companies which have social and environmental responsibilities. In this way, Bhattacharya et al. (2008b) proclaim that CSR activities comprise a legitimate, compelling and increasingly important way to attract and retain good employees as well as a good tool to satisfy customers with the aim to differentiate the company from its competitors in the market. Considering this background and relevance about CSR and HRM, this paper proposes a conceptual framework with two main goals: firstly, to explain the relationships between both fields; and secondly, to examine the external and internal adjustment that firms must carry out to achieve competitive advantages from this process. 
Table 1 Empirical studies on the relationship between CSR and performance

\begin{tabular}{|c|c|c|c|}
\hline Study & Country & Data & Findings \\
\hline $\begin{array}{l}\text { Waddock and } \\
\text { Graves (1997) }\end{array}$ & EE.UU. & 469 firms & $\begin{array}{l}\text { Companies that carry out a set of CSR practices to } \\
\text { improve the relationship with their stakeholders } \\
\text { (employees, customers, communities and environment) } \\
\text { and consequently increase their financial performance }\end{array}$ \\
\hline $\begin{array}{l}\text { Hillman and } \\
\text { Keim }(2001)\end{array}$ & EE.UU. & 308 firms & $\begin{array}{l}\text { There is a positive correlation between CSR and the value } \\
\text { creation for the stakeholders and the shareholders of the } \\
\text { company }\end{array}$ \\
\hline $\begin{array}{l}\text { Simpson and } \\
\text { Kohers (2002) }\end{array}$ & EE.UU. & 385 firms & $\begin{array}{l}\text { There is a positive link between CSR actions and social } \\
\text { and financial performance of a enterprise }\end{array}$ \\
\hline $\begin{array}{l}\text { Déniz-Déniz and } \\
\text { De Sáa Pérez } \\
\text { (2003) }\end{array}$ & Spain & 50 firms & $\begin{array}{l}\text { Companies that engage socially responsible human } \\
\text { resources practices meet the expectations of their } \\
\text { employees, achieving greater performance and } \\
\text { commitment from this group as a result }\end{array}$ \\
\hline $\begin{array}{l}\text { Tsoutsoura } \\
(2004)\end{array}$ & EE.UU. & 500 firms & $\begin{array}{l}\text { There is a positive linkage between CSR and financial } \\
\text { performance that enables to invest in a improvement of } \\
\text { employee relations, environmental concerns and } \\
\text { community relations }\end{array}$ \\
\hline $\begin{array}{l}\text { Mittal et al. } \\
(2008)\end{array}$ & India & 50 firms & $\begin{array}{l}\text { Companies that implement CSR initiatives (codes of } \\
\text { ethics and conduct that listed in their annual reports) } \\
\text { generate a significant economic and market value }\end{array}$ \\
\hline $\begin{array}{l}\text { Rettab et al. } \\
(2009)\end{array}$ & Dubai & 280 firms & $\begin{array}{l}\text { CSR has a positive impact on organisational performance: } \\
\text { financial performance, employee commitment and } \\
\text { corporate reputation }\end{array}$ \\
\hline $\begin{array}{l}\text { Surrroca et al. } \\
(2010)\end{array}$ & Spain & 599 firms & $\begin{array}{l}\text { CSR practices provide an improvement of intangible } \\
\text { variables of the organisation (innovation, human capital, } \\
\text { reputation, culture and economic performance) }\end{array}$ \\
\hline
\end{tabular}

Source: Own elaboration.

\subsection{External adjustment of CSR}

Companies play a vital role in the development and welfare of society (employment generation, economic wealth, distributing goods and services, etc.), so they must assume additional responsibilities that go beyond their economic and legal obligations (Davis, 1960). In this sense, many organisations have incorporated social, ethical and environmental commitments to meet the society and stakeholder's expectations (Logsdon and Wood, 2002; Matten and Crane, 2005). The expression of these commitments has resulted in the integration of CSR by a large number of companies in order to legitimate their activity and increase their competitiveness (Aguilera et al., 2007; McWilliams and Siegel, 2001; Porter and Kramer, 2006). On the other hand, organisations that manage their resources in an irresponsible manner are punished with heavy criticism by the market. This causes an erosion of their image and value, damaging seriously their stakeholder's relations (Dowling, 2004; Sen and Bhattacharya, 2001). Some relevant examples of the social impact of firms are the accounting manipulations of information by Enron Corporation, the environmental pressures on Shell Oil's or the pressures on Nike about their employment policies (Wheeler et al., 2003). These companies were forced to redirect their behaviour towards sustainability models to adapt to society 
requirements (Global Reporting Initiative, 2002, 2006; Principles for Responsible Management Education, 2009). For these reasons, literature based on the stakeholders approach underlines the importance of considering the needs of the firms interest groups (society, government, customers, suppliers, employees, shareholders, etc.) who can affect the firm's outcomes (Argandoña, 1998; Barnett, 2007).

According to the instrumental view of stakeholder theory, companies that combine the satisfaction of the interest groups with the accomplishment of its objectives can conduct their activities with greater guarantees of success as well as improve the relations with these groups (Donaldson and Preston, 1995; Jones, 1995; Odgen and Watson, 1999). Likewise, the process of adjustment between companies and their environment requires the internalisation of a set of institutional factors by firms in order to be accepted by the community and achieve more competitiveness (Dacin, 1997; Dacin et al., 2008; Scott, 2001). Thus, Meyer and Rowan $(1977,1991)$ and DiMaggio and Powell (1983) show how organisations that:

1 mimic the practices and strategies of greater success companies in their markets mimetic isomorphism

2 establish and maintain good relations with their stakeholders - coercive isomorphism

3 get the support and institutional legitimacy of their community - normative isomorphism

can improve their market position, image, reputation and, consequently, their economic returns enhancing as a result a better adjustment with their context (Husted and Salazar, 2006; Mackey et al., 2007; Weaver et al., 1999).

In this paper, we focus on the coercive isomorphism. Concretely, we study the relationships between company and its employees as internal stakeholders. According to Lockwood (2004) and Sharma et al. (2009), workers play a key role in the development of CSR strategies. The level of employees' participation increases the welfare of firms as well as provides internal benefits from their commitment and loyalty (Brammer et al., 2007; Collier and Esteban, 2007; Cullen et al., 2003). A strong organisational culture reinforced by responsible HR management practices can ensure high levels of success in the market by the improvement of employee's satisfaction, their productivity, customer loyalty, legal compliance and the approval of society (Sharma et al., 2009). For these reasons, a strategic approach in the way of managing human capital can be crucial in the process of integrating CSR (Fuentes-García et al., 2008). Based on these arguments, our second objective is to explain the benefits that organisations can achieve by developing and implementing a CSR orientation in their HR practices.

\subsection{Internal adjustment of CSR}

Regarding the company's internal frame, literature stresses the importance of linking business strategy to HRs practices for improving the organisational performance (Becker and Gerhart, 1996; Miles and Snow, 1984; Youndt et al., 1996). The SHRM concept as Martín-Alcazar et al. $(2005,2008)$ mentioned represents an evolution of the traditional concept of HRs towards a new integrative perspective which include: a vertical link with the strategic management process, a horizontal link with the HR practices and an external link with other organisational and environment factors. The review on SHRM underlines that HR system can be a unique source of sustainable competitive advantage if there is a 
fit between its internal and external components (Lengnick-Hall and Lengnick-Hall, 1988; Wright and McMahan, 1992). Muncherji and Gupta (2004) examine, in this sense, how sociocultural values can affect the development and building of HR practices in organisations. Recently, Peters et al. (2009), and Galbreath $(2009,2010)$ have discussed about the implications and benefits of a social phenomenon like CSR on organisation's strategy and their performance. The analyses of both authors suggest that CSR cannot be separated from corporate strategy, showing an important gap of research between CSR and the HR strategy. Considering these theoretical dissertations, this study aims to analyse whether a fit between business strategies towards CSR and the configuration of the HR practices can be in the long term a source of sustainable competitive advantages for enterprises. In addition, this paper explores if certain improvements in variables such as work environment and intellectual capital can positively affect the organisational performance as a result of HR practices with a socially responsible orientation. Thus, our first research proposition is:

Proposition 1: Companies that develop a socially responsible orientation in their strategy can achieve sustainable competitive advantages.

Different studies and research in CSR show how the integration of a social orientation in the firm's strategy can impregnate the HR policies and practices as well as the organisational culture of the company (fair labour rights, health and safety, quality of work, etc.) (Brammer et al., 2007; Greening and Turban, 2000; Peters and Vassar (2009); Peterson, 2004). According to the Commission of the European Communities (2001) and the Global Reporting Initiative $(2002,2006)$, this paper has focused on five socially responsible practices to analyse their effects on organisational performance:

1 appropriate employment relations and working conditions

2 communication, employee involvement and social dialogue

3 education and training

4 occupational health and safety

5 diversity and equal opportunities.

Hence, the second proposition is:

Proposition 2: Companies that develop a socially responsible orientation in their strategy should extend these values to its HR practices.

According to the literature, HR practices with socially responsible guidance can improve the working environment within the company (Gould-Williams, 2007; Patterson et al., 2004; Rogg et al., 2001). Moreover, in a context in which workers are treated fairly and equitably it is easier to create a work environment based on harmony and welfare, where the employees feel more committed and happy, reaching in this way in the long term more productivity and efficiency (Aguilera et al., 2007; Dutton et al., 1994; Phusavat et al., 2009). In this regard:

Proposition 3: A socially responsible orientation in the HRs practices can provide an improvement of the working environment of organisations. 
Additionally, the improvements in the working environment facilitate the communication, trust and cooperation among its members - social capital (Adler and Kwon, 2002; Nahapiet and Ghoshal, 1998). A positive work environment encourages the relations and the frequency of formal and informal communication within organisation, providing a higher cohesion among employees and the achievement of organisational goals (structural dimension of social capital) (Chen et al., 2009; Galán and Castro, 2004; Tsai and Ghoshal, 1998). This network of relations enhances the trust and reciprocity among workers, facilitating a collective welfare and a stronger commitment between them (relational dimension of social capital) (Prusak and Cohen, 2001; Putnam, 2001). The improvement and quality of the relationships promote an exchange of knowledge, skills and their experience among employees - human capital, increasing in this way the intellectual capital within the organisation, encouraging the achievement of sustainable competitive advantages through this capital (Youndt and Snell, 2004). Hence, our third and four propositions are:

Proposition 4: An improvement of working environment resulting from socially responsible HRs practices can increase the intellectual capital of organisations.

Proposition 5: Companies with a socially responsible orientation in their HRs practices can achieve competitive advantages resulting from an improvement in the intellectual capital of organisations.

The research propositions are reflected in the conceptual model shown below (Figure 1).

Figure 1 Conceptual model

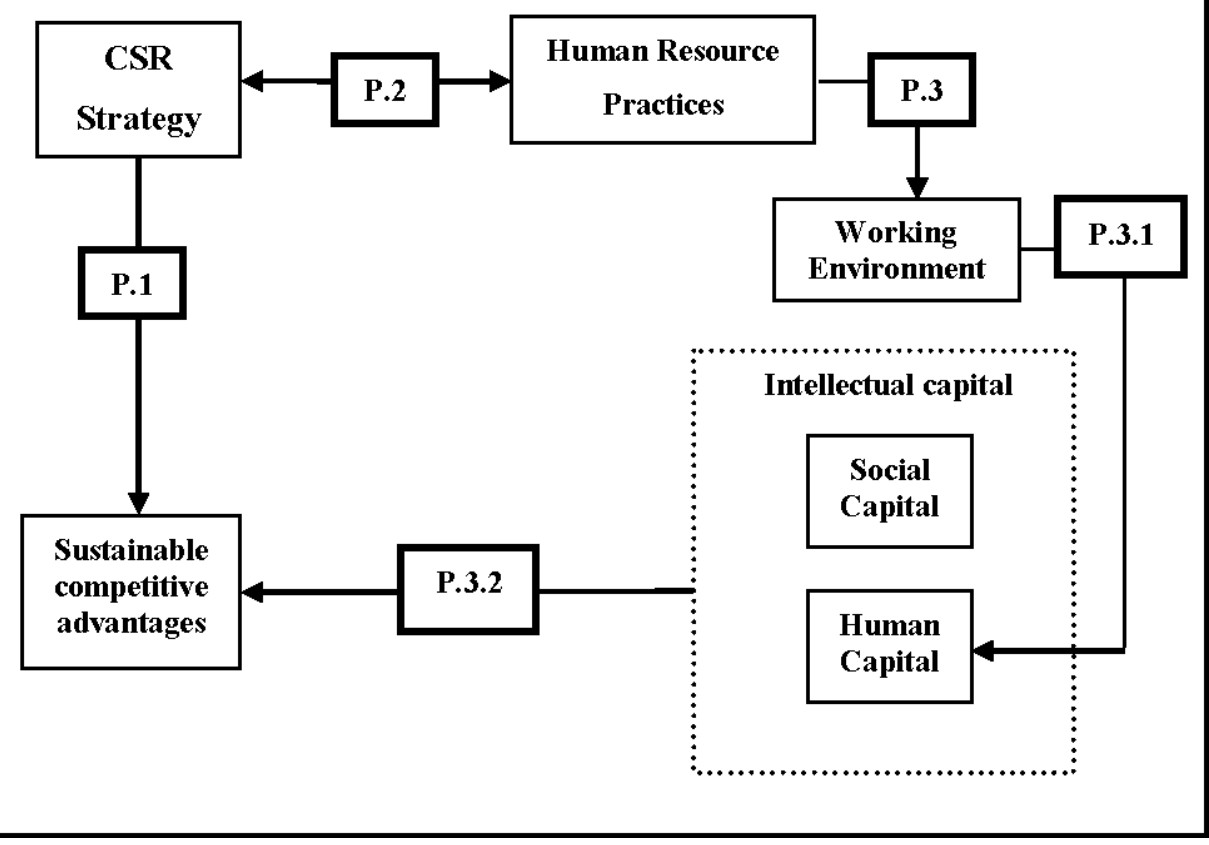

Source: Own elaboration. 


\section{Concluding remarks}

This paper examines the issues of development and testing of a conceptual model which analyses the casual relationships between CSR and SHRM. The literature review shows the importance of institutional factors (Campbell, 2007; DiMaggio and Powell, 1983; Scott, 2001) and stakeholder's expectations in the internal and external adjustment process of CSR (Aguilera et al., 2007; Barnett, 2007; Donaldson and Preston, 1995). Specifically, this study has focused on employees due to the importance of human capital in the process of integrating CSR strategies (Lockwood, 2004; Sharma et al., 2009).

The research objectives proposed are:

1 analysing how a external and internal fit regarding CSR can provide competitive advantages for organisations

2 show the benefits that organisations can achieve by developing and implementing CSR in their HR practices and strategies.

Our review indicates that the development of a socially responsible orientation in HR practices (Brammer et al., 2007; Greening and Turban, 2000; Peterson, 2004) allows companies to obtain an improvement in variables, such as working environment (Bowen and Ostroff, 2004; Gould-Williams, 2007) and intellectual capital (Kang and Snell, 2009; Youndt and Snell, 2004), leading to obtaining sustainable competitive advantages through this process. According to a report published by PricewaterhouseCoopers $(\mathrm{PWC})^{2}$ in 2010 aimed at managers and professionals of different parts of the world, recruitment and retention of talent are one of the most important current concerns of organisations regardless of their size. The professional consultant underscores that the $85 \%$ of HR managers believe that attracting and retaining talented people can offer companies a significant long-term advantage of differentiation, which could result in a positive way to their account results. It is clear that companies must provide in their HR practices: issues and social improvements which can meet the expectations of their current and prospective employees.

Therefore, the integration of CSR in the field of SHRM represents an opportunity to improve the engagement, sense of belonging and productivity of employees (Brammer et al., 2007; Collier and Esteban, 2007). CSR has become in this sense, in a key partner that contributes to the value's generation in the HR management, helping to retain and motivate the human capital and improving the firm's performance and sustainability of firm's (Aguilera et al., 2007; Galbreath, 2009). To sum up policies and organisational practices represent the principal initiatives of HRM to internalise social responsibility and ensure that CSR issues become part of the firms (Agrawal, 2007).

\section{Future research}

This research is at an early stage of analysis and construction of the theoretical framework. Once the propositions can be tested, we will offer a series of indicators to clarify and quantify the benefits of HR policies with a socially responsible orientation. The sample of this study will compose of large-scale Spanish companies (more than 500 employees) that have HR department, belonging to different industry sectors in order to contrast the institutional theory and make comparisons. 
Based on Dess and Davis (1984) and Robinson and Pearce (1988), we will develop three questionnaires aimed at the general managers, HR directors and employees in order to analyse the following issues:

1 strategy of the company

2 internal measures of CSR

3 strategies and HR policies

4 intellectual capital

5 working environment

6 organisational performance.

The questionnaire uses a Likert scale to measure these items. We will use the social categories of practices from KLD Analytics, Inc. (http://www.kld.com) and the GRI (http://globalreporting.org) to analyse the effects on employee and organisational performance. Regarding intellectual capital, we follow the methodology proposed by Bontis et al. (1999) and Hung (2004) to structure and measure the intangible asset in three different aspects: structural, social and human capital. Moreover according to McGuire et al. (1988), we consider expert evaluations and also the content of annual CSR reports and other corporate documents to contrast the information. Depending on the number of valid responses and the progress of the investigation, we will determine the statistical methodology to implement different analysis techniques. Through the statistical results, we will proceed to contrast the hypotheses and analysis of the conclusions reached in the academic and professional field. Likewise, there is a great interest in analysing the social orientation of HR practices in other countries to make comparisons. In this sense, Brewster $(1995,1999)$ and Gooderham et al. (1999) show that the environment influences the performance and corporate strategies as well as the development of the HRs policies.

Another significant aspect could be studying the effects of socially responsible HR policies in social capital dimensions: structural and cognitive. Schoemaker et al. (2006) proposed that CSR can be integrated with greater effectiveness in organisations where social capital is more developed. In addition, Degli-Antoni and Saconi (2010), propose the idea of a virtuous circle between the different levels of social capital and the implementation of CSR practices, encouraging the creation of a cooperative networks between the firm and all its stakeholders as well as the promotion of social norms of trust, trustworthiness and cooperation. For these reasons, social capital plays an important role in the process of integration and development of CSR.

Finally, the effective implementation of HR strategy, oriented towards social responsibility, not only depends on the variables that we have showed. The status of individual employees (behaviours, attitudes, reactions, experiences, job satisfaction, etc.) and the perception that they have about the organisation and carrying out their policies are very important in the process of implementation CSR (Liao and Rupp, 2005). According to Colquitt et al. (2001), workers feel more identified, satisfied and engaged with companies that exercise social responsibility. Therefore, we believe that contributions based on organisational justice theory (Fortin, 2008; Rupp et al., 2006) can help us to analyse the behaviour of employees in the process of implementing CSR through the analysis of three kinds of employee's perceptions: procedural, distributive and interactional. 


\section{References}

Adler, P. and Kwon, S. (2002) 'Social capital prospects for a new concept', The Academy of Management Review, Vol. 27, No. 1, pp.27-40.

Agrawal, K. (2007) 'Corporate excellence as an outcome of corporate governance: rethinking the role and responsibility of HRM', ICFAI Journal of Corporate Governance, Vol. 6, No. 1, pp.6-16.

Aguilera, R., Rupp, D., Williams, C. and Ganapathi, J. (2007) 'Putting the S back in corporate social responsibility: a multilevel theory of social change in organization', Academy of Management Review, Vol. 32, No. 3, pp.836-863.

Argandoña, A. (1998) 'The stakeholder theory and the common good', Journal of Business Ethics, Vol. 17, No. 9, pp.1093-1102.

Arthur, J. and Boyles, T. (2007) 'Validating the human resource system structure: a levels-based strategic HRM approach', Human Resource Management Review, Vol. 17, No. 1, pp.77-92.

Barnett, M. (2007) 'Stakeholder influence capacity and the variability of financial returns to corporate social responsibility', Academy of Management Review, Vol. 32, No. 3, pp.794-816.

Becker, B. and Gerhart, B. (1996) 'The impact of human resource management on organizational performance: progress and prospects', The Academy of Management Journal, Vol. 39, No. 4, pp.779-801.

Bhattacharya, C., Korschun, D. and Sen, S. (2008a) 'Strengthening stakeholder-company relationships through mutually beneficial corporate social responsibility initiatives', Journal of Business Ethics, Vol. 85, No. 2, pp.257-272.

Bhattacharya, C., Sen S. and Korschun, D. (2008b) 'Using corporate social responsibility to win the war for talent', MIT Sloan Management Review, Vol. 49, No. 2, pp.37-44.

Bontis, N., Dragonetti, N., Jacobsen, K. and Ross, G. (1999) 'The knowledge toolbox: a review of the tools available to measure and manage intangible resources', European Management Journal, Vol. 17, No. 4, pp.391-402.

Bowen, D. and Ostroff, C. (2004) 'Understanding HRM-firm performance linkages: the role of the strength of the HRM system', Academy of Management Review, Vol. 29, No. 2, pp.203-221.

Brammer, S., Millington, A. and Rayton, B. (2007) 'The contribution of corporate social responsibility to organizational commitment', Int. J. Human Resource Management, Vol. 18, No. 10, pp.1701-1719.

Brewster, C. (1995) 'Towards a European model of human resource management', Journal of International Business Studies, Vol. 26, No. 1, pp.1-21.

Brewster, C. (1999) 'Strategic human resource management: the value of different paradigms', Management International Review, Vol. 39, No. 3, pp.45-64.

Burgman, R. and Ross, G. (2007) 'The importance of intellectual capital reporting: evidence and implications', Journal of Intellectual Capital, Vol. 8, No. 1, pp.7-51.

Campbell, J. (2007) 'Why would corporations behave in socially responsible ways? An institutional theory of corporate social responsibility', Academy of Management Review, Vol. 32, No. 3, pp.946-967.

Carmeli, A., Ben-Hador, B., Waldman, D. and Rupp, D. (2009) 'How leaders cultivate social capital and nurture employee vigor: implications for job performance', Journal of Applied Psychology, Vol. 94, No. 6, pp.1553-1561.

Carroll, A. (1999) 'Corporate social responsibility: evolution of a definitional construct', Business and Society, Vol. 38, No. 3, pp.268-295.

Carroll, A. and Shabana, K. (2010) 'The business case for corporate social responsibility: a review of concepts, research and practice', Int. J. Management Reviews, Vol. 12, No. 1, pp.85-105.

Chen, C., Lin, T., Liou, Y. and Liu, Y. (2009) 'Social capital, knowledge-based view and entrepreneurial opportunity', Int. J. Management and Enterprise Development, Vol. 7, No. 2, pp.163-182. 
Clarkson, M. (1995) 'A stakeholder framework for analyzing and evaluating corporate social performance', Academy of Management Review, Vol. 20, No. 1, pp.92-117.

Collier, J. and Esteban, R. (2007) 'Corporate social responsibility and employee commitment', Business Ethics: A European Review, Vol. 16, No. 1, pp.19-33.

Colquitt, J., Conlon, D., Wesson, M., Porter, C. and Ng, K. (2001) 'Justice at the millennium: a meta-analytic review of 25 years of organizational justice research', Journal of Applied Psychology, Vol. 86, No. 3, pp.425-445.

Commission of the European Communities (2001) Green Book: Promoting a European Framework for Corporate Social Responsibility. Brussels: European Commission.

Crane, A., McWilliams, A., Matten, D., Moon, J. and Siegel, D. (2008) The Oxford Handbook of Corporate Social Responsibility. Oxford: Oxford University Press.

Cuganesan, S. (2006) 'Reporting organisational performance in managing human resources: intellectual capital or stakeholders perspectives?', Journal of Human Resource Costing and Accounting, Vol.10, No. 3, pp.164-188.

Cullen, J., Praveen, P. and Victor, B. (2003) 'The effects of ethical climates on organizational commitment: a two study analysis', Journal of Business Ethics, Vol. 46, No. 2, pp.127-141.

Dacin, M. (1997) 'Isomorphism in context: the power and prescription of institutional norms', Academy of Management Journal, Vol. 40, No. 1, pp.46-81.

Dacin, M., Kostova, T. and Roth, K. (2008) 'Institutional theory in the study of multinational corporations: a critique and new directions', Academy of Management Review, Vol. 33, No. 4, pp.994-1006.

Davis, K. (1960) 'Can business afford to ignore its social responsibilities?', California Management Review, Vol. 2, No. 3, pp.70-76.

Degli-Antoni, G. and Saconi, L. (2010) 'Modeling cognitive social capital and corporate social responsibility (CSR) as preconditions for sustainable networks of relations', EconomEticam, Working Paper No. 19, March.

Déniz-Déniz, M. and De Sáa Pérez, P. (2003) ‘A resource based view of corporate responsiveness toward employees', Organization Studies, Vol. 24, No. 1, pp.299-319.

Dess, G. and Davis, P. (1984) 'Porter's (1980) 'Generic strategies as determinants of strategic group membership and organizational performance', Academy of Management Journal, Vol. 27, No. 3, pp.467-488.

DiMaggio, P. and Powell, W. (1983) 'The iron cage revisited: institutional isomorphism and collective rationality in organizational fields', American Sociological Review, Vol. 48, No. 2, pp.147-160.

Donaldson, T. and Preston, L. (1995) 'The stakeholder theory of the corporation: concepts, evidence and implications', Academy of Management Review, Vol. 20, No. 1, pp.65-91.

Dowling, G. (2004) 'Corporate reputations; should you compete on yours?', California Management Review, Vol. 46, No. 3, pp.19-36.

Dutton, J., Dukerich, J. and Harquail, C. (1994) 'Organizational images and member identification', Administrative Science Quarterly, Vol. 39, No. 1, pp.239-263.

Evans, W. (2005) 'High-performance work systems and organizational performance: the mediating role of internal social structure', Journal of Management, Vol. 31, No. 5, pp.758-775.

Fortin, M. (2008) 'Perspectives on organizational justice: concept clarification, social context integration, time and links with morality', Int. J. Management Reviews, Vol. 10, No. 2, pp.93-126.

Freeman, R. (1984) Strategic Management: A Stakeholders Approach. Boston: Pitman.

Freeman, R., Harrison, J., Wicks, A., Parmar, B. and De Colle, S. (2010) Stakeholder Theory: The State of the Art. Cambridge: Cambridge University Press.

Fuentes-García, F., Nuñez-Tabales, J. and Veroz-Herradón, R. (2008) 'Applicability of corporate social responsibility to human resources management: perspective from Spain', Journal of Business Ethics, Vol. 82, No. 1, pp.27-44. 
Galán, J. and Castro, I. (2004) 'Las relaciones interorganizativas como fuente de capital social', Universia Business Review, Vol. 2, pp.104-117.

Galbreath, J. (2009) 'Building corporate social responsibility into strategy', European Business Review, Vol. 21, No. 2, pp.109-127.

Galbreath, J. (2010) 'How does corporate social responsibility benefit firms? Evidence from Australia', European Business Review, Vol. 22, No. 4, pp.411-431.

Garavan, T. and McGuire, D. (2011) 'Human resource development and society: human resource development's role in embedding corporate social responsibility, sustainability, and ethics in organizations', Advances in Developing Human Resources, Vol. 12, No. 5, pp.487-507.

Global Reporting Initiative (2002) Sustainability Reporting Guidelines. Boston, MA: GRI.

Global Reporting Initiative (2006) Sustainability Reporting Guidelines. Amsterdam, The Netherlands: GRI.

Gómez-Mejía, L. and Balkin, D. (2002) Management. New York: McGraw-Hill.

Gooderham, P., Nordhaug, O. and Ringdal, K. (1999) 'Institutional and rational determinants of organizational practices: human resource management in European firms', Administrative of Science Quarterly, Vol. 44, No. 3, pp.507-531.

Gould-Williams, J. (2007) 'HR practices, organizational climate and employee outcomes: evaluating social exchange relationships in local government', Int. J. Human Resource Management, Vol.18, No. 9, pp.1627-1647.

Greening, D. and Turban, D. (2000) 'Corporate social performance as a competitive advantage in attracting a quality workforce', Business and Society, Vol. 39, No. 3, pp.254-280.

Harrison, J. and Freeman, R. (1999) 'Stakeholders, social responsibility, and performance: empirical evidence and theoretical perspectives', Academy of Management Journal, Vol. 42, No. 5, pp.479-485.

Hillman, A. and Keim, G. (2001) 'Shareholder value, stakeholder management, and social issues: What's the bottom line?', Strategic Management Journal, Vol. 22, No. 1, pp.125-139.

Hung, Y. (2004) 'A conceptual model for evaluating intellectual capital systems: an empirical study of a high-tech company in Taiwan', Int. J. Management and Enterprise Development, Vol. 1, No. 3, pp.285-299.

Husted, B. and Allen, D. (2007) 'Strategic corporate social responsibility and value creation among large firms: lessons from the Spanish experience', Long Range Planning, Vol. 40, No. 1, pp.594-610.

Husted, B. and Salazar, J. (2006) 'Taking Friedman seriously: maximizing profits and social performance', Journal of Management Studies, Vol. 43, No. 1, pp.75-91.

Jones, T. (1995) 'Instrumental stakeholder theory: a synthesis of ethics and economics', Academy of Management Review, Vol. 20, No. 1, pp.404-437.

Kang, S. and Snell, S. (2009) 'Intellectual capital architectures and ambidextrous learning: a framework for human resource management', Journal of Management Studies, Vol. 46, No. 1, pp.65-92.

Leana, C. and Van Buren, H. (1999) 'Organizational social capital and employment practices', The Academy of Management Review, Vol. 24, No. 3, pp.538-555.

Lengnick-Hall, C. and Lengnick-Hall, M. (1988) 'Strategic human resource management: a review of the literature and a proposed typology', Academy of Management Review, Vol. 13, No. 3, pp.454-470.

Lengnick-Hall, M., Lengnick-Hall, C., Andrade, L. and Drake, B. (2009) 'Strategic human resource management: the evolution of the field', Human Resource Management Review, Vol. 19, No. 1, pp.64-85.

Lepak, D., Liao, H., Chung, Y. and Harden, E. (2006) 'A conceptual review of human resource management systems in strategic human resource management research', Research in Personnel and Human Resources Management, Vol. 25, No. 1, pp.217-271. 
Liao, H. and Rupp, D. (2005) 'The impact of justice climate, climate strength, and justice orientation on work outcomes: a multilevel framework', Journal of Applied Psychology, Vol. 90, No. 2, pp.242-256.

Lockett, A., Moon, J. and Visser, W. (2006) 'Corporate social responsibility in management research: focus, nature, salience and sources of influence', Journal of Management Studies, Vol. 43, No. 1, pp.115-136.

Lockwood, N. (2004) 'Corporate social responsibility: HR's leadership role', SHRM Research Quarterly, Vol. 4, December.

Logsdon, J. and Wood, D. (2002) 'Business citizenship: from domestic to global level of analysis', Business Ethics Quarterly, Vol. 12, No. 2, pp.155-188.

Mackey, A., Mackey, T. and Barney, J. (2007) 'Corporate social responsibility and firm performance: investor preferences and corporate strategies', Academy of Management Review, Vol. 32, No. 3, pp.817-835.

Martín-Alcazar, F., Romero-Fernández, P. and Sanchez-Gardey, G. (2005) 'Strategic human resource management: integrating the universalistic, contingent, configurational and contextual perspectives', Int. J. Human Resource Management, Vol. 16, No. 5, pp.633-659.

Martín-Alcazar, F., Romero-Fernandez, P. and Sanchez-Gardey, G. (2008), 'Human resource management as a field of research', British Journal of Management, Vol. 19, No. 2, pp.103-119.

Matten, D. and Crane, A. (2005) 'Corporate citizenship: toward an extended theoretical conceptualization', Academy of Management Review, Vol. 30, No. 1, pp.166-180.

McGuire, J., Sundgreen, A. and Schneeweis, T. (1988) 'Corporate social responsibility and firm financial performance', Academy of Management Journal, Vol. 31, No. 4, pp.854-872.

McWilliams, A. and Siegel, D. (2001) 'Corporate social responsibility: a theory of the firm perspective', Academy of Management Review, Vol. 26, No. 1, pp.117-127.

Meyer, J. and Rowan, B. (1977) 'Institutionalized organizations: formal structure as myth and ceremony', American Journal of Sociology, Vol. 83, No. 2, pp.340-363.

Meyer, J. and Rowan, B. (1991) 'Institutionalized organizations: formal structure as myth and ceremony', in W. Powell and P. DiMaggio (Eds.), The New Institutionalism in Organization Analysis. Chicago, IL: University of Chicago Press, pp.41-62.

Miles, R. and Snow, C. (1978) Organizational Structure, Strategy and Process. New York: McGraw-Hill.

Miles, R. and Snow, C. (1984) 'Designing strategic human resource systems', Organizational Dynamics, Vol. 13, No. 1, pp.36-52.

Mittal, R., Sinha, N. and Singh, A. (2008) 'An analysis of linkage between economic value added and corporate social responsibility', Management Decision, Vol. 46, No. 9, pp.1437-1443.

Moran, P. (2005) 'Structural vs. relational embeddedness: social capital and managerial performance', Strategic Management Journal, Vol. 26, No. 12, pp.1129-1151.

Muncherji, N. and Gupta, O. (2004) 'Role of human resource management in developing ethnic and diverse enterprises', Int. J. Management and Enterprise Development, Vol. 1, No. 2, pp.155-163.

Nahapiet, J. and Ghoshal, S. (1998) 'Social capital, intellectual capital and the organizational advantage', The Academy of Management Review, Vol. 23, No. 2, pp.242-266.

Odgen, S. and Watson, R. (1999) 'Corporate performance and stakeholder management: balancing shareholder and customer interest in the U.K. privatized water industry', Academy of Management Journal, Vol. 42, No. 5, pp.526-538.

Peters, R., Koufteros, X. and Berman, S. (2009) 'Corporate social responsibility and the chief executive officer: determinants of a positive strategic intention towards corporate social responsibility', Int. J. Management and Enterprise Development, Vol. 6, No. 1, pp.38-54.

Peters, R. and Vassar, J. (2009) 'The international flavours of corporate social responsibility', Int. J. Management and Enterprise Development, Vol. 7, No. 4, pp.382-393. 
Peterson, D. (2004) 'The relationship between perceptions of corporate citizenship and organizational commitment', Business and Society, Vol. 43, No. 3, pp.296-319.

Patterson, M., Warr, P. and West, M. (2004) 'Organizational climate and company productivity: the role of employee affect and employee level', Journal of Occupational and Organizational Psychology, Vol. 77, No. 2, pp.193-216.

Phusavat, K., Anussornnitsarn, P., Rassameethes, B. and Kess, P. (2009) 'Productivity improvement: impacts from quality of work life', Int. J. Management and Enterprise Development, Vol. 6, No. 4, pp.465-478.

Porter, M. and Kramer, M. (2006) 'Strategy and Society', Harvard Business Review, Vol. 84, No. 1, pp.78-92.

PricewaterhouseCoopers Report (2010) 'CSR trends 3: a comprehensive survey of corporate social responsibility trends, benchmarks and best practices', Available at: http://www.pwc.com/ en_CA/ca/sustainability/publications/csr-trends-3-en.pdf, March 2011.

Principles for Responsible Management Education (2009) Red Española del Pacto Mundial de Naciones Unidas, November, Madrid, Available at: http://www.unprme.org, April 2010.

Prusak, L. and Cohen, D. (2001) 'How to invest in social capital', Harvard Business Review, Vol. 79, pp.86-93.

Putnam, R. (2001) 'Social capital: measurement and consequences' in the contribution of human and social capital to sustained economic growth and well-being', in OECD and HRDC (Eds.), International Symposium Report.

Rettab, B., Brik, A. and Kamel, M. (2009) 'A study of management perceptions of the impact of corporate social responsibility on organisational performance in emerging economies: the case of Dubai', Journal of Business Ethics, Vol. 89, No. 1, pp.371-390.

Robinson, R. and Pearce, J. (1988) 'Planned patterns of strategic behaviour and their relationship to business-unit performance', Strategic Management Journal, Vol. 9, pp.43-60.

Rogg, K., Schmidt, D., Schull, C. and Schmidt, N. (2001) 'Human resources practices, organizational climate, and customer satisfaction', Journal of Management, Vol. 27, No. 4, pp.431-449.

Rupp, D., Ganapathi, J., Aguilera, R. and Williams, C. (2006) 'Employee reactions to corporate social responsibility: an organizational justice framework', Journal of Organizational Behaviour, Vol. 27, No. 4, pp.537-543.

Schoemaker, M., Nijhof, A. and Jonker, J. (2006) 'Human value management: the influence of the contemporary developments of CSR and social capital on HRM', Management Revue, Vol. 17, No. 4, pp.448-465.

Scott, W. (1995) Institutions and Organizations: Foundations for Organizational Science. Sage: Beverly Hills.

Scott, W. (2001) Institutions and Organizations (2nd ed.). Thousand Oaks, CA: Sage.

Sen, S. and Bhattacharya, C. (2001) 'Does doing good always lead to doing better? Consumer reactions to corporate social responsibility', Journal of Marketing Research, Vol. 38, No. 2, pp.225-244.

Sharma, S., Sharma J. and Devi, A. (2009) 'Corporate social responsibility: the key role of human resource management', Business Intelligence Journal, Vol. 2, pp.205-213.

Simpson, W. and Kohers, T. (2002) 'The link between corporate social and financial performance evidence from the banking industry', Journal of Business Ethics, Vol. 35, No. 2, pp.97-109.

Sirota Survey Intelligence (2007) 'Employer commitment to corporate social responsibility linked to employee attitudes', Available at: http://www.sirota.com/ sirota/pdfs/Employer Commitment_To_Corporate_Social_Responsibility_Linked_To_Employee_Attitudes_May $\% \overline{2}$ 0_007.pdf, March 2011.

Surrroca, J., Tribó, J. and Waddock, S. (2010) 'Corporate responsibility and financial performance: the role of intangible resources', Strategic Management Journal, Vol. 31, No. 1, pp.1-49. 
Tsai, W. and Ghoshal, S. (1998) 'Social capital and value creation: the role of intrafirm networks', The Academy of Management Journal, Vol. 41, No. 4, pp.464-476.

Tsoutsoura, M. (2004) 'Corporate social responsibility and financial performance', Working Paper, Haas School of Business, University of California, Berkeley, Available at: http://www. haas.berkeley.edu/responsiblebusiness/documents/FinalPaperonCSR_PDFII.pdf, April 2010.

Waddock, S. and Graves, S. (1997) 'The corporate social performance-financial performance link', Strategic Management Journal, Vol. 18, No. 4, pp.303-319.

Weaver, G., Trevino, L. and Cochran, P. (1999) 'Integrated and decoupled corporate social performance: management commitments, external pressures and corporate ethics practices', Academy of Management Journal, Vol. 42, pp.539-552.

Wheeler, D., Colbert, B. and Freeman, R. (2003) 'Focusing on value: reconciling corporate social responsibility, sustainability and a stakeholder approach in a network world', Journal of General Management, Vol. 28, No. 3, pp.1-29.

World Business Council for Sustainable Development (2000) Corporate Social Responsibility: Making Good Business Sense. Geneva: WBCSD.

Wright, P., Dunford, B. and Snell, S. (2001) 'Human resources and the resource based view of the firm', Journal of Management, Vol. 27, No. 6, pp.701-721.

Wright, P. and McMahan, G. (1992) 'Theoretical perspectives for strategic human resource management', Journal of Management, Vol. 18, No. 2, pp.295-320.

Youndt, A. and Snell, S. (2004) 'Human resource configurations, intellectual capital and organizational performance', Journal of Management Issues, Vol. 16, No. 3, pp.337-360.

Youndt, A., Snell, S., Dean, J. and Lepak, D. (1996) 'Human resource management, manufacturing strategy, and firm performance', Academy of Management Journal, Vol. 39, No. 4, pp.836-866.

\section{Notes}

${ }^{1}$ Sirota is a private company that works with clients (private, public and not-for-profit) committed to the sharing of industry best practices, improvement of certain aspects of employee, customer relations and stakeholder research in general. Source: Available at: http://www.sirota.com/.

${ }^{2}$ PWC offers multidisciplinary solutions, designed to help companies effectively position themselves and move towards a sustainable business model. With more than 6,000 professionals in over 100 country clubs, the PWC network has one of the world's largest human resource organisations advisory. Source: Available at: http://www.pwc.com. 